БУХГА ЛТЕРСЬКИЙ ОБЛІК, АНА ЛІЗ ТА АУДИТ

UDC 336

DOI: https://doi.org/10.32782/2520-2200/2020-1-37

\author{
Liba Natalia \\ Mukachevo State University \\ Holovachko Vasyl \\ Mukachevo State University
}

\begin{abstract}
Ліба Н.C.
доктор економічних наук, доцент, доцент кафедри обліку і оподаткування та маркетингу Мукачівського державного університету
\end{abstract}

Головачко В.М.

кандидат економічних наук, доцент, доцент кафедри обліку і оподаткування та маркетингу, Мукачівського державного університету

\title{
LOCAL TAXES AND CHARGES AND THEIR ROLE IN THE FORMATION OF TAX RECEIPTS OF LOCAL BUDGETS IN UKRAINE
}

\section{МІСЦЕВІ ПОДАТКИ І ЗБОРИ ТА ЇХНЯ РОЛЬ У ФОРМУВАННІ ПОДАТКОВИХ НАДХОДЖЕНЬ МІСЦЕВИХ БЮДЖЕТІВ В УКРАЇНІ}

With the proclamation of Ukraine's independence, the process of formation of the state tax system has actually begun. At the same time, the process of improving the system of taxation of the state as one of the signs of a sovereign state is still ongoing, which is confirmed by annual changes to the tax legislation. This is due both to the socio-economic conditions of Ukraine's development as a democratic and rule of law, requiring senior officials to review the principles of legal regulation of a number of priority social relations, some of which are social relations in the field of taxation, and to the European integration processes in the country, which have intensified significantly in recent years. The article deals with the nature of local taxes and fees that come to local budgets. The classification of local taxes and fees is reviewed. The mechanism of collecting local taxes and fees is shown. Local taxes and fees in the 2017-2018 budget of Ukraine are analyzed.

Key words: local budget, property tax, single tax, land tax, tourist tax, transportation tax, parking fee, reform, taxation system, local taxes and fees.

3 проголошенням Україною незалежності фактично розпочався процес становлення системи оподаткування держави. При цьому на сьогодні процес удосконалення системи оподаткування держави як однієї з ознак суверенної держави ще триває, що підтверджується щорічними змінами до податкового законодавства. Це пов'язано як із соціально-економічними умовами розвитку України як демократичної та правової держави, що вимагають від вищих посадових осіб перегляду засад правового регулювання ряду пріоритетних суспільних відносин, одними з яких є суспільні відносини у сфері оподаткування, так і з євроінтеграційними процесами в державі, що впродовж останніх років істотно активізувалися. У період поступової європейської інтеграції актуальним питанням для України є також можливість перейняти досвід зарубіжних країн щодо формування місцевого бюджету. Відповідно вивчення ефективних систем місцевого оподаткування та їх впровадження в Україні є необхідними передумовами реформування системи оподаткування на місцевому рівні. Враховуючи той факт, що в Україні триває процес адаптації національного податкового законодавства до вимог Європейського Союзу, слід зазначити, що сьогодні головним завданням України на шляху інтеграції до Європейського Союзу є адаптація національного податкова система до стандартів та вимог Європейського Союзу. Інститут місцевих податків і зборів є важливим для формування доходів місцевих органів влади в найбільш розвинених країнах. Ратифікувавши Європейську хартію місцевого самоврядування та проголосивши інтеграцію до ЄС як один із напрямків подальшого розвитку економіки. Україна змушена поступово адаптувати систему формування доходів бюджету до умов та стандартів Європейського Союзу. Саме тому питання вдосконалення системи 
місцевих податків і зборів в Україні набуває актуальності сьогодні. Стаття присвячена дослідженню сутності місцевих податків та зборів, що надходять до місцевих бюджетів. Здійснено огляд класифрікації місцевих податків та зборів. Показано механізм справляння місцевих податків та зборів. Проаналізовано надходження місцевих податків і зборів до бюджету України 2017-2018 рр.

Ключові слова: місцевий бюджет, податок на майно, єдиний податок, плата за землю, туристичний збір, транспортний податок, збір за місця для паркування транспортних засобів, реформування, система оподаткування, місцеві податки і збори.

С провозглашением Украиной независимости фактически начался процесс становления системы налогообложения государства. При этом на сегодня процесс совершенствования системы налогообложения государства как одного из признаков суверенного государства еще продолжается, что подтверждается ежегодными изменениями в налоговом законодательстве. Это связано как с социально-экономическими условиями развития Украины как демократического и правового государства, требуют от высших должностных лиц просмотра основ правового регулирования ряда приоритетных общественных отношений, одним из которых являются общественные отношения в сфере налогообложения, так и с евроинтеграционными процессами в государстве, что в последние годы существенно активизировались. Статья посвящена исследованию сущности местных налогов и сборов, поступающих в местные бюджеты. Осуществлен обзор классификации местных налогов и сборов. Показан механизм взимания местных налогов и сборов. Проанализированы поступления местных налогов и сборов в бюджет Украины 2017-2018 гг.

Ключевые слова: местный бюджет, налог на имущество, единый налог, плата за землю, туристический сбор, транспортный налог, сбор за места для парковки транспортных средств, реформирования, система налогообложения, местные налоги и сборы.

Formulation of the problem. An effective and efficient system of local self-government is an important element in the functioning of a democratic state. In order to ensure the fulfillment of its functions, the creation of a proper living environment for the community, local governments should have sufficient financial resources, the basis of which is the corresponding budgets. One of the important sources of revenue for local government budgets is local taxes and charges.

The analysis of recent researches and publications. Problems and analysis of local taxes and charges have been investigated by the following domestic and foreign scholars: O.V. Bezkrovnyj, N.V. Bortnik, R.E. Voloshchuk, L.P. Sidelnykova, T.V. Chizhova, Ya.V. Yakusha, V.I. Garvanko, L.I. Prostebi. In the works of these scholars, the mechanism of administration and regulation of local taxes and fees, the economic foundations of filling local budgets have been explored.

The purpose of the article is to characterize and analyze the local taxes and cgarges coming to local budgets.

Outline of the main research material. Each administrative and territorial unit has a legally enshrined right to economic autonomy, so it must have its own budget, managing without external interference. Local budgets are the basis of the financial status of the local self-government, which deals with financing of educational institutions, culture, public health, mass media, social protection of the population. Within the current domestic tax system, the basic concepts are enshrined: tax as a mandatory, unconditional payment to the corresponding budget, paid by the taxpayers; col- lection (charges, contribution) as a compulsory payment to the respective budget, collected by the payers of the fees, under the condition that they will receive special benefits. The right to set local taxes and charges is enshrined in Art. 143 of the Constitution of Ukraine by the bodies of local self-government. Thus, according to paragraph 24 of Part 1 of Art. 26 of the Law on Local Self-Government, these issues are solved exclusively at the planned meetings of the village, settlement, city council [2].

Figures of the share of primary income of all taxpayers redistributed through the budgetary system of Ukraine and the dynamics of revenues of its budgets during 2013-2018 have been presented in Fig. 1-2.

In general, the indicators of the dynamics of the revenues of the budgetary system of Ukraine during 2013-2018 outline its significant dependence on tax revenues, where the share in the revenues of the consolidated, state and local budgets is $80.31 \% ; 79.12 \% ; 84.27 \%$ respectively. At the same time, there is a tendency to increase budget centralization, since a significant amount of revenues is concentrated in the state budget, while the level of decentralization is insufficient. In addition, this is the evidence that the state, while accumulating tax payments through the budgets, removes a significant part of the income of their payers. At the same time, this means that as a result of governmental fiscal decisions and the next amendments to the Tax Code of Ukraine, the level of tax burden on the subjects of the national economy is increasing, as well as the fact that the state activity is growing faster than the social 


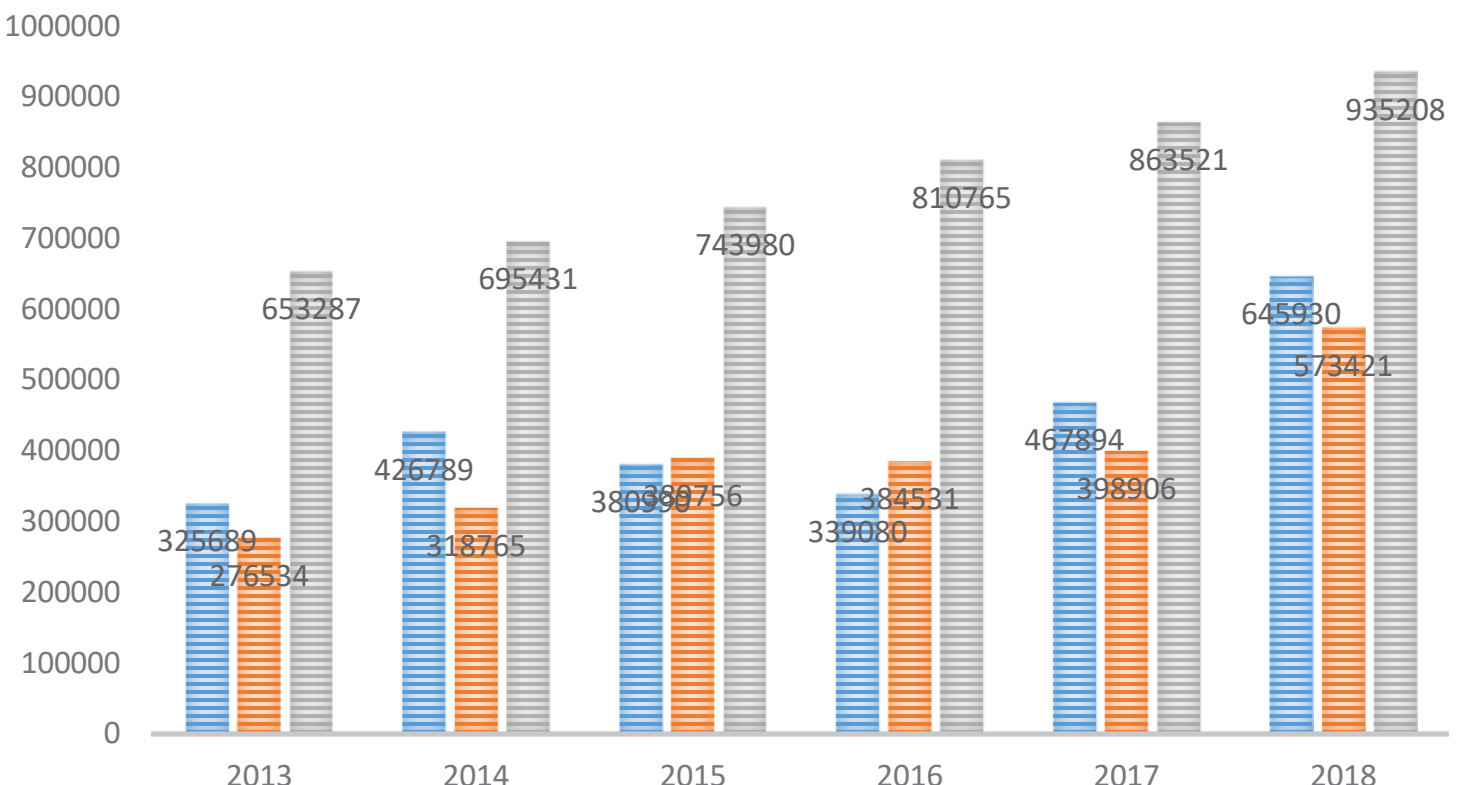

Figure 1. Indicators of the dynamics of Ukraine's budget revenues of consolidated, state and local incomes

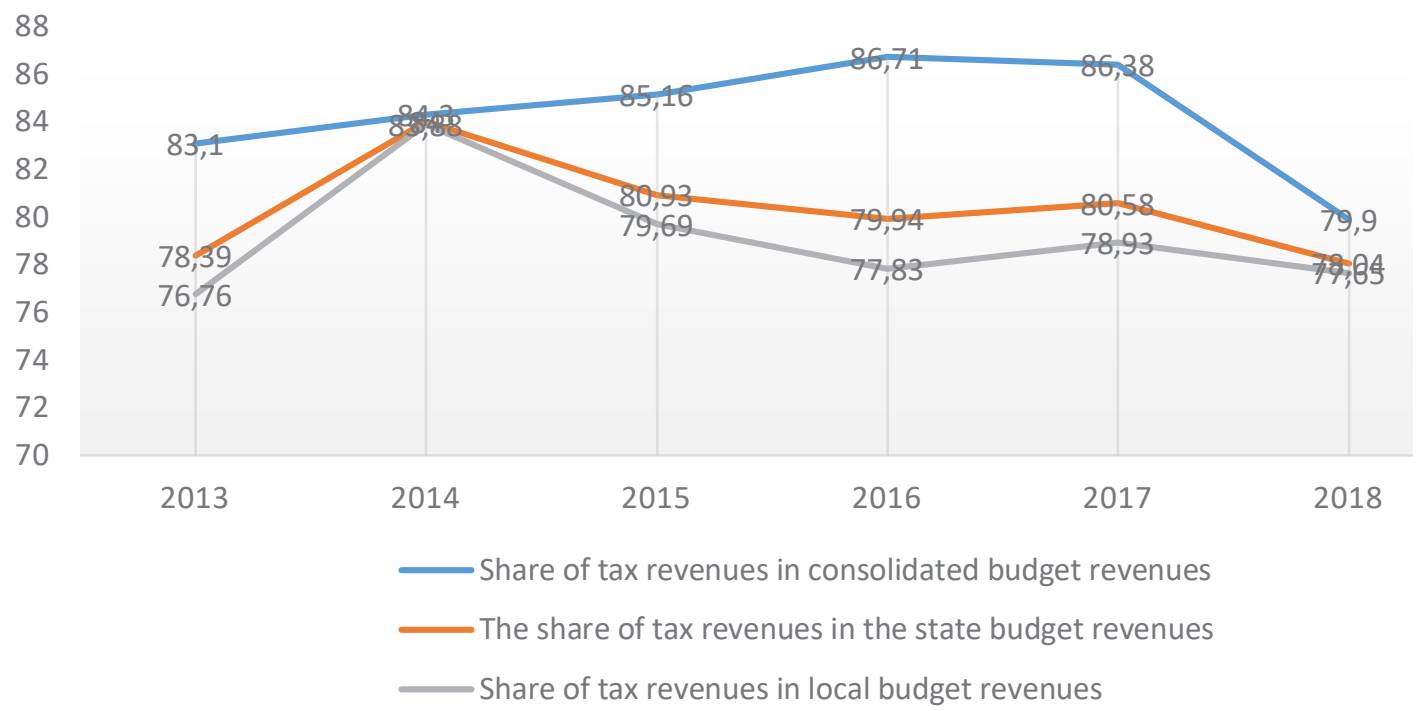

Figure 2. Indicators of the share formation through tax revenues of Ukraine's budgets

and economic development in the country. In the future, under these conditions, fiscal policy means will slow down the economic growth of GDP and negatively affect the budget revenues.

The reasons for this situation are, first of all, the downsides of lawmaking, leading to a conflict of interest between taxpayers and fiscal authorities. However, the regulatory framework that underlies modern fiscal policy has several shortcomings, namely: the list of legal acts is too large and the acts themselves are quite difficult to put into practice; legislative acts do not always clearly and fully describe the rules of law, leading to a large number of by-laws; the imperfection of regulations leads to the adoption of numerous amendments.

In Ukraine, according to Article 10 of the Tax Code, local taxes include a property tax and a single tax, while local charges include parking fees and tourist taxes.

Local councils are required to set a single property tax and property tax (as regards transport tax and land payments). Whereas the question of establishing a property tax (in the part of a fixed property tax differs from land) and establishing a fee for parking spaces, the tourist charge is decided by the local councils within the scope of their powers determined by the CCU [3]. 
A single tax is a tax paid by business entities on a simplified tax system. Actual single tax revenues for January-December 2018 amounted to $\mathrm{UAH} 29487,7$ billion. The main feature of a single tax is that it replaces several taxes at once.

Single tax payers are divided into the following groups:

1) the first group - natural persons - entrepreneurs who do not use the work of hired persons, carry out exclusively retail sale of goods. The amount of their income during the calendar year does not exceed UAH 300,000;

2) the second group - natural persons - entrepreneurs who carry out business activities for providing services, production and sale of goods, activities in the field of restaurant business, provided that during the calendar year: they do not use the employment of employees or their number does not exceed 10 people *; their income does not exceed UAH 1500000.

3) the third group - natural persons - entrepreneurs who do not use the work of hired persons or the number of persons who are with them in employment cooperation, are not limited and legal entities - entities of any legal form, in which during the calendar the amount of income does not exceed UAH 5 million;

4) the fourth group is agricultural producers in which the share of agricultural commodity production for the previous tax (accounting) year is $75 \%$ and more. In this case, newly established agricultural producers can only pay a single tax from the following year, provided that the share of income from the sale of agricultural products in the previous tax (reporting) year is equal to or exceeds $75 \%$.

Fixed rates of a single tax are set by local councils, depending on the type of business, per calendar month. In particular:

1) for the first group of taxpayers the fixed rate of the single tax is set up to $10 \%$, but from the amount of the subsistence minimum for able-bodied persons, which is $192.10 \mathrm{UAH}$;

2) for the second group of the single tax - up to 20 percent of the minimum salary, which amounts to UAH 834.60;

The same single tax rate for third-party payers is set as a percentage of their income, namely:

$3 \%$ - apply VAT payers of group 3 ;

$5 \%$ - apply VAT not-payers of group 3;

For single taxpayers of the fourth group, the size of the tax rates per 1 ha of agricultural land and / or lands of the water fund depends on the category (type) of land and their location.

The tax (reporting) period for single tax payers of the first, the second and the fourth groups is a calendar year. The tax (reporting) period begins on the first day of the first month of the tax (report- ing) period and ends on the last calendar day of the last month of the tax (reporting) period.

Instead, for taxpayers of the single tax of the third group, the tax (reporting) period is equal to the calendar quarter. The third group single tax payers pay a single tax within 10 calendar days after the tax filing deadline for the tax (reporting) quarter [4].

Tax on a fixed property

General requirements for tax on fixed property differ from the land, established by Art. 266 PKU. The taxpayers are natural and legal persons, including non-residents, who own residential and / or non-residential real estate located within the territory of the respective community.

The tax base is the total area of the residential and non-residential property, including its parcels. According to Clause 266.5 of the PC, tax rates are set by decision of the village, settlement or city council, depending on the location (zoning) and types of such real estate in the amount not exceeding 1.5 percent of the minimum salary established by law on 01 January of the reporting (tax) year, for 1 sq. m. tax base. 25000 UAH per year - in addition to the indicated $1.5 \%$ for $1 \mathrm{sq}$. $\mathrm{m}$. is charged for apartments and houses of more than 300 square meters and 500 square meters respectively.

The base tax (reporting) period is the calendar year.

Transport tax.

The taxpayers are natural and legal persons, including non-residents, who have their own passenger cars registered in Ukraine under the current legislation.

In turn, the object of taxation is cars, which have been issued no more than 5 years (inclusive), and the average market value of which is more than 375 minimum salaries, established by law as of January 1 of the tax (reporting) year.

The rate of this tax is set at the rate of UAH 25 thousand per calendar year for each passenger car that meets the criteria for tax deduction.

Accordingly, the basic tax (reporting) period for this tax is the calendar year.

Land payment is a compulsory payment in the form of property tax, which is collected in the form of land tax and rent for state and communal property. Land payments for January-December 2018 amounted to UAH 27319.1 billion. Land tax should be considered as a compulsory payment for land owners and parcels and permanent land users. And rent for state and communal property must be considered as the obligatory payment that the tenant makes to the landlord for the use of the land.

For example, the tax rate for land, the regulatory monetary policy (hereinafter referred to as RMP) is 
set at no more than $3 \%$ of their RMP. For public lands no more than $1 \%$ of their RMP and for agricultural land not less than $0.3 \%$ and no more than $1 \%$ of their RMP. The maximum rate of tax for land in permanent use by economic entities (excluding state and municipal ownership) is $12 \%$ of their RMP.

The basic tax (reporting) period for the land payment is the calendar year. The tax (reporting) year begins on January 1 and ends on December 31 of the same year [5].

Parking charge for vehicles

The payers of this levy are legal entities, their branches (offices, representative offices), as well as natural persons-entrepreneurs, who, according to the decision of the relevant council, organize and carry out activities to ensure the parking of vehicles on paid parking areas and specially designated parking lots.

The tax base is the area of land allocated for parking, as well as the area of communal garages, parking lots, parking places (buildings, structures, their parts), which are built at the expense of the local budget. The collection rate shall be set for each day of activity for providing parking of vehicles in UAH per $1 \mathrm{~m} 2$ of the area of the designated land. The rate of this levy is $0.075 \%$ of the MPE established by law as of January 1 of the tax (reporting) year.

The base tax (reporting) period for collecting parking spaces is equal to the calendar quarter [1].

A tourist fee is a local charge, which is credited to the local budget. Tourist tax is set in accordance with the requirements of Art. 268 PKU. The payers of this fee are citizens of Ukraine, foreigners, as well as stateless persons, who are in the territory of the respective community and receive (consume) temporary residence (overnight) services with an obligation to leave the residence within the specified period.

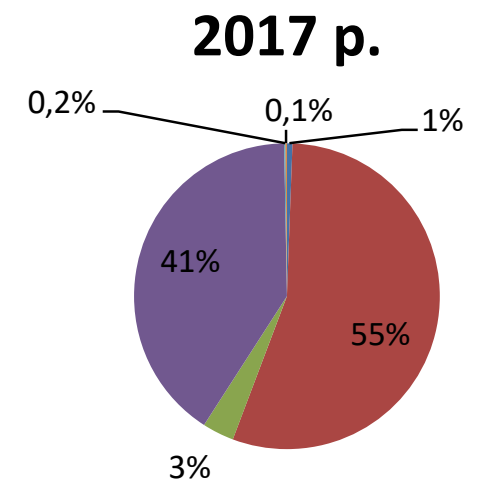

Single tax

Transport tax

Parking fees for vehicles

Payment for fixed property differing from land
The base for collecting the tourist tax is the cost of the entire stay (nights) in the places mentioned above, excluding VAT.

The tourist tax rate is set at 0.5 to $1 \%$ of the collection rate. The peculiarity of collecting this fee is that tax agents do this when providing services related to temporary accommodation (overnight), and indicate the amount of the fee paid as a separate line in the invoice (receipt). The basic tax (reporting) period for the tourist tax is the calendar quarter.

With the help of reforms of the territorial organization of the authorities, since 2014 they have been able to improve the financial capacity of local budgets. This is confirmed by the increase of the share of local budget revenues in the consolidated budget of Ukraine from $17 \%$ in 2015 to $22 \%$ according to the results of 2018.

Taking into account the various changes that have occurred in the tax legislation, the influence of the self-government bodies on the introduction and mobilization of local taxes and fees, it is possible to trace the dynamics of their share in the revenues of local budgets of Ukraine.

As a result of improved revenue mobilization and a change in the structure of local taxes and fees, their share in local budget revenues has increased significantly in recent years. If from 2011 to 2014 their share was $8.8 \%$, then in 2018 it was already $24.7 \%$ [5].

On Figure 3 shows that the largest share in the structure of local taxes and fees is received from land payments (over $50 \%$ ) and a single tax (40\%). This testifies to the gradual development of small and medium-sized businesses in Ukraine.

The lowest share is the tourist tax and the fee for parking spaces (less than 1\%). Therefore, for further increasing of local budget revenues, it is necessary to create conditions for tourism

Figure 3. Structure of local taxes and fees of Ukraine for 2017-2018 
development in different cities of Ukraine. And also provide additional paying parking spaces, thus solving the problem of lack of free parking spaces and the problem of parking in unauthorized places.

For example, local taxes and fees are an important part of Mukachevo city budget revenues. Their share in the amount of own revenues of the general fund of the city budget in 2018 is $19.2 \%$, and the actual amount of their revenues is in the amount of 109065,5 thousand UAH. Compared to the corresponding period of the previous year, revenues have increased by UAH 2,543.7 thousand. or $2.4 \%$. In the structure of local taxes and levies in 2018 , single tax $(62.6 \%)$ and property $\operatorname{tax}(37.2 \%)$ accounted for the largest share. It should be noted that the most important part of the property tax is the payment for land, its share in local taxes and fees is $31.6 \%$. The dynamics and structures of Mukachevo city's local taxes and fees over the last five years are shown in Table 1.
Conclusions. Thus, rationally organized local budgeting will help to develop the region's well-being and improve the quality of life of the population, so the studying of the place of local taxes and fees plays an important role in developing a fair and efficient tax system in the country in accordance with the principles of a democratic system. The analysis of local taxes and fees is an important source of information on the condition of payments in the state, so it is significant to understand the methodology and features of this topic, as well as to be aware of all the tax changes and features. Timely and accurate information on local taxes and fees is necessary to analyze the performance of the enterprise, which will prevent errors in the future, will allow the enterprise to optimize the tax burden and to contribute to the development of the region, since taxes payment is one of the main sources of financing the local budgets.

Table 1

\section{Dynamics and structure of local taxes and fees of Mukachevo}

\begin{tabular}{|c|c|c|c|c|c|}
\hline Local taxes & 2014 & 2015 & 2016 & 2017 & 2018 \\
\hline 1. Tax on property & 11874,7 & 15940,4 & 30654,1 & 49665,7 & 40573,4 \\
\hline $\begin{array}{l}\text { 1.1. Fixed property tax differing from land, paid by legal } \\
\text { entities that own the objects of residential real estate }\end{array}$ & 140,4 & 80,0 & 53,9 & 115,3 & 238,7 \\
\hline $\begin{array}{l}\text { 1.2. Fixed property tax differing from land, paid by } \\
\text { natural persons who are the owners of residential } \\
\text { real estate }\end{array}$ & 11,5 & 120,0 & 317,4 & 568,1 & 814,1 \\
\hline $\begin{array}{l}\text { 1.3. Fixed property tax differing from land, paid by } \\
\text { natural persons owning non-residential real estate }\end{array}$ & - & - & 174,3 & 517,6 & 1317,5 \\
\hline $\begin{array}{l}\text { 1.4. Fixed property tax differing from land, paid by } \\
\text { legal entities owning non-residential real estate }\end{array}$ & 0,0 & 620,0 & 1026,1 & 2898,7 & 2917,2 \\
\hline 1.5. Land tax of legal entities & 5879,1 & 7850,0 & 1871,2 & 3222,0 & 2382,1 \\
\hline 1.6. Rent payment of legal entities & 2720,5 & 4600,0 & 6520,6 & 8269,5 & 8043,8 \\
\hline 1.7. Land tax of natural persons & 879,2 & 1090,0 & 1664,6 & 1608,8 & 1604,6 \\
\hline 1.8. Rent payment of natural persons & 1244,0 & 1100,0 & 1887,4 & 2347,0 & 1403,9 \\
\hline 1.9. Transport tax of natural persons & 0,0 & 370,4 & 313,3 & 274,5 & 334,0 \\
\hline 1.10. Transport tax of legal entities & 0,0 & 110,0 & 225,3 & 244,2 & 417,5 \\
\hline 2. Tourist tax & 34,3 & 58,0 & 92,2 & 108,1 & 137,7 \\
\hline $\begin{array}{l}\text { 3. Fee for conducting certain types of business } \\
\text { activities, completed before } 1 \text { January } 2015\end{array}$ & 1419,4 & 0,0 & $-40,3$ & $-12,9$ & 2,2 \\
\hline 4. Single tax & 25912,8 & 28095,0 & 39946,6 & 56760,9 & 68352,2 \\
\hline Total & 39241,2 & 44093,4 & 70652,6 & 106521,8 & 109065,5 \\
\hline
\end{tabular}

References:

1. Zbir za miscja dlja parkuvannja transportnykh zasobiv [Parking fees for vehicles]. Available at: https://services.dtkt.ua/catalogues/other_dov/105 (accessed 23.01.2020).

2. Stankus T. (2017) Miscevi podatky i zbory [Local taxes and fees]. Available at: https://old.decentralization.gov.ua/pics/attachments/2017-03-Miiscevii_podatkii_ii_zborii_DESPRO.pdf (accessed 09.12.2019).

3. Podatkovyj kodeks Ukrajiny [Tax Code of Ükraine: Law No. 2755-VI of 02.12.2010. Database "Legislation of Ukraine" / VR of Ukraine]. Available at: http://zakon3.rada.gov.ua/ laws/card/2755-17 (accessed 22.01.2020).

4. Bjudzhetnyj kodeks Ukrajiny [Budget Code of Ukraine: Law, Code of Ukraine No. 2456-VI of 8 July 2010]. Available at: http://zakon4.rada.gov.ua/laws/show/2456-17. (accessed 22.01.2020).

5. Miscevi podatky ta zbory [Local taxes and fees]. Available at: http://decentralization.gov.ua/uploads/ library/file/261/Buklet_-_Miscevi_podatky_pereghljad____.pdf. (accessed 03.12.2019). 


\section{Список використаних джерел:}

1. Збір за місця для паркування транспортних засобів. URL: https://services.dtkt.ua/catalogues/ other_dov/105 (дата звернення: 23.01.2020).

2. Станкус Т. Місцеві податки і збори. Харків, 2017. URL: https://old.decentralization.gov.ua/pics/ attachments/2017-03-Miiscevii_podatkii_ii_zborii_DESPRO.pdf (дата звернення: 09.12.2019).

3. Податковий кодекс України: Закон від 02.12.2010 № 2755-VI. База даних «Законодавство України» / BP України. URL: http://zakon3.rada.gov.ua/ laws/card/2755-17 (дата звернення: 22.01.2020).

4. Бюджетний кодекс України: Закон, Кодекс України № 2456-VI від 08.07.2010 p. URL: http://zakon4.rada.gov.ua/laws/show/2456-17. (дата звернення: 22.01.2020).

5. Місцеві податки та збори. URL: http://decentralization.gov.ua/uploads/library/file/261/Буклет_Місцеві_податки_перегляд__1_.pdf. (дата звернення: 03.12.2019). 